\title{
Death-Drive America: On Scott Wilson's Vision of the Cultural Politics of American Nihilism in the Age of Supercapitalism
}

\author{
Mark Featherstone
}

\section{Against the Bipolar Culture of Americanism}

Despite the explosion of academic study of American political theology in recent times, I hold the view that the best single work on the fundamentalist turn in American politics under Bush II is Arthur Kroker's (2006) short book Born Again Ideology. However, this view has recently been challenged by the appearance of two books on contemporary America by the British cultural theorist Scott Wilson. What makes Wilson's books on American supercapitalism, which should really be labeled volumes one and two of a single study of contemporary American political culture, extremely important is that they provide a coherent philosophical and cultural exposition of contemporary America that historicizes the fundamentalist turn under Bush II and presents the Bush, Cheney, Rumsfeld neoconservative regime as less the driving force behind the turn to fundamentalism and more the politicalcultural representation of a tendency in American history that has always been present. Kroker's book is essential for the same reason. There are, of course, other studies which cover the same ground, including James Morone's (2003) excellent Hellfire Nation, but none of these offer the same level of philosophical sophistication as the Kroker or Wilson books.

Where Wilson differs from Kroker is in his sustained use of psychoanalysis and cultural theory to explicate the structures of contemporary American society that enables the reader to situate the Bush II regime in a philosophical context comparable to those that exist for the great modern utopias-dystopias of Nazi Germany and Stalin's Soviet Union (Arendt 1973). In other words, where Kroker's book delivers the story of American quantum culture and vampyric techno-theology through a close reading of American culture itself, Wilson provides the interpretation of the deep structure of this strange cultural form through a close reading of the poststructuralist tradition in French thought. Although some realist readers may complain that both Kroker and Wilson are hyperbolic in their interpretations of America, I would suggest that it is precisely the surrealistic tone of both writers that makes their books essential, because it is this super-realistic vision that enables them to reveal the madness of contemporary American culture and overcome the tendency to normalization that is present in every society, never mind those where the exception has become the rule. It is for this reason, which often means that those books that are most necessary are paradoxically completely underexposed to commentary and discussion, that what I offer in this paper is a critical analysis of Wilson's essential theory of American political culture under Bush II.

The first point to note is that Wilson's books are particularly timely in that they offer us an image of the America of Bush II in its last days. As I read Wilson's texts America was already consumed with Obama's utopian talk of change, and it was easy to think that the cruel landscape of what we might call death drive America was about to be swept away forever by at best Obama's utopian politics, which would apparently see the world united behind a new tolerant brand of Americanism, or at worst McCain's Bush-lite, which would never be able to hit the highs or lows of the Bush II regime because of the failure or, as Wilson's books explain, the success of the latter in its black 
policy drives. But simply because Obama came out of top, and America entered a new utopian phase of thinking about itself as liberator of others through rule of law rather than iron fist, does not mean that Wilson's books on the cultural politics of the America of Bush II represent irrelevant historical documents. Although it is clear that America has now entered a liberal phase, which as Kroker (2006) explains is the less violent other side of American quantum culture, it is not clear that the social, culture, and psychological complex of Americanism that endlessly propels the land of the free through the bipolar cycle of religious ultra-conservatism and secular liberalism has been completely or even partially recognized.

As Kroker's (2006) shows, the central reason why it is difficult for America to reflect upon its cultural psychopathology is that the connection between religion and reason runs right through to the core of American identity itself to the extent that even the two-party political system is a reflection of its psychopathological bipolarity. This is why it will not be enough for Obama to simply turn away from what Wilson shows to be the Bataillean politics of Bush II. If Obama's own utopianism, which is colored by nods towards social justice rather than Bush II's focus on advancing the law of nature, is no more than the latest in a long line of more or less centrist versions of American liberalism, then the bipolarity of American culture will remain unchallenged. This is what Kroker and the subject of this paper Wilson show. The real change America needs will require a radical re-evaluation of its national, cultural, psyche on top of a turn away from the surrealistic political economy of Bush II. That this will only be possible by interrogating the deep structures of Americanism is what makes Wilson's books important beyond the Bush II period, into the Obama presidency, and most probably long into the future.

What Wilson's books offer is precisely this psychological analysis of the deep structures of Americanism that is necessary to not only critically engage with the totalitarian or, to use Paul Virilio's (Virilio in Armitage 2001) term, globalitarian aspects of the American psyche, but also excavate the progressive or utopian element of the thought of the inhabitants of the land of the free. As I have shown in my own work, Tocqueville's Virus (2007), this utopian impulse which runs through Americanism, and can be traced back to the original settlers, read out of the works of Hobbes and Locke, and detected in the politics of Wilson, FDR, and Obama, is the other side of the death dealing, sacrificial, psychological temper Wilson associates with the Freudian (2003) notion of thanatos.

Although thanatos may be essential, because as Deleuze (1991) shows in his work on the psychology of sadism, the dystopic rhythms of the death drive are always prior to the secondary impulse of eros, the life drive that prevents humans simply destroying themselves in the name of a return to Mom. I think there is a sense in which America needs to confront its own death drive in order that it may better engage its progressive, utopian, impulse. In the age of globalization and global capitalism, I think this is now more urgent than ever before because the reach of the death drive America is more or less total, as evidenced by dystopic notions such as full spectrum dominance, and the original utopians, the European heirs to Plato and More, who for so many centuries sought the realization of an imaginary social and political ideal, have long since seen their idealism collapse into cynical realpolitik under the unbearable weight of the memories of Auschwitz and the Gulag Archipelago. This is why we need to take Wilson's books deadly seriously. They offer a dark dystopic image of America that may be enough to cause us to think about the ways in which America can return to its progressive, utopian, tradition under conditions of globalization that make confronting profound philosophical, psychoanalytic, questions of utopia, dystopia, life, and death more pressing than ever before.

\section{The Mystical Order of Joy and the Supercapitalist Death Drive}

On the face of it is difficult to see how what I take to be the first volume of Wilson's study of Americanism, The Order of Joy (2008a), delivers the form of cultural re-evaluation that will be necessary for America to recognize, and consequently master, its own unique brand of quantum culture. The book seems to be a standard philosophical document working through connections between various French structuralisms and poststructuralisms, and it is hard to see what it could say about America, beyond a passing similarity between some aspects of French thought and American culture. However, the relation between French thinking and American culture the book establishes is much deeper and much more convincing than first impressions suggest. The deep meaning of the book, and the psychological complex which roots the exploration of American culture to come in both texts, resides in the equation of pleasure, death, and joy made early in the book. This connection, which it would be easy to miss because it appears on the first page of the book, relates back to Wilson's earlier work on Georges Bataille, with the important 
development that Bataille's link between pleasure and death is augmented through reference to Deleuze's concept of joy that describes the sensation of perfect mechanization (Wilson 2008a).

Given the addition of the notion of joy, Wilson's thesis is not simply that a kind of sensuous violence pervades contemporary American culture, and that this is paradoxically the product of a repressive Puritan society, but rather that the fusion of religion and technology in America creates a limit situation defined by perfect mechanization that recalls the mythic state of joyess rapture where the chosen people leave their fleshy earthbound bodies behind and ascend towards the heavens to become one with God. It is through reference to this thesis, which recalls Achille Mbembe's (2003) work on necropolitics, that Wilson shows how America has evolved a mystical culture of negation, where technological death and destruction is necessary for the elevation of particular humans to a joyess new state. What is more is that this runs parallel to the Islamic fundamentalists' apocalyptic cult of death of the suicide bomber, which transforms the ghoulish spectacle of the exploding body into a cause for celebration. That is to say that in much the same way that the Islamic fundamentalist body explodes when it reaches the joyess state of maximum intensity represented by the condition of martyrdom before God, the American techno body pushes towards the limit condition of organic death through a culture of techno-theology that aspires to reach the mystical state of oneness with the divine through a state of perfect mechanization that would render the fleshy body obsolete and signal the emergence of posthuman cybernetic man.

Given that this psychocultural apocalyptic structure has, as Kroker (2006) shows, been central to American thought from the very beginning illustrates why it will not be enough for Obama to simply turn back to multilateral politics and away from the empire talk of Bush II. In Kroker's theory of American postmodern ideology, what happened under Bush II is that the ancient Old Testament Puritanism of the original settlers came back to enchant the postmodern techno-politics of post-Berlin Wall America that was already gripped by the messianic language of the end of history. Thus, the thinkers who inform Kroker's vision of the America of Bush II are Einstein and Weber who illustrate the possibility of a quantum culture where religion and techno-reason fuse to form an apocalyptic complex that is endlessly thrown back to the future in search of salvation. It is this image of technoPuritan America that Wilson (2008a; 2008b) extends in his books through French theory, with the added value that the psychoanalytic basis of his work may provide some way out of the psychological complex of quantum culture through the recognition of the way the compulsion of repeat sustains the bipolarity of Americanism. In other words, through recognition it may be possible to work through and eventually overcome the condition of bipolarity that currently means that the conservative-paranoid line through Eisenhower, Nixon, Reagan, and Bush II will never end. This is, essentially, the therapeutic model that sustains the Freudian-Lacanian theory that Wilson employs in his books to explain the structure of the order of joy that he believes organizes American culture.

In order to extend this psychoanalytic model to an analysis of American cultural politics Wilson makes use of Lacan's three registers of the imaginary, which usually refers to the subject's imagined self, the symbolic order, which relates to the systems of language and culture that structure human reality, and the real, which Lacan employs to explain the hard core of organic existence that can never be represented by either the imaginary or the symbolic order and persists on the outer edge of human perception. Wilson employs this triadic structure of the imaginary, the symbolic order, and the real to refer to the body of global capitalism, the state, and the general economy of war and expenditure. In his Lacanian complex, then, the imaginary is represented by the totality of global capitalism, the symbolic order is reflected in the state that provides significance and codes the image of the global economy, and the real is embodied by the practices of war, violence, and expenditure understood in the widest sense. Regarding the fusions between the three registers, Wilson explains that economy and war meet in the explosion of joyful immanence linked to destruction and consumption, war and state collide in the production of the mode of anorganic joy related to perfected mechanization, and the state and economy meet in the event of the symbolization of empire.

The nightmarish picture of neo-liberal America that emerges over the course of the first chapter of The Order of Joy (2008a) is, therefore, one of a state set on the total domination of global space-time through the endless expansion of a martial economic model that is based on that mechanistic consumption of organic matter and is for this reason totally impervious to human reason. While Kroker (2006) paints a similarly bleak picture of American empire in his outstanding companion piece to Born Again Ideology, The Will to Technology (2003), through the use of Marx, Nietzsche, and Heidegger, Wilson fast forwards through Kroker's essential texts Capital (1990), Thus Spoke Zarathustra (2003a), and The Question Concerning Technology (1977), until he reaches Deleuze and Guattari's (1972; 1984) books on capitalism and schizophrenia, which become the core texts for his work on contemporary Americanism. In respect of the use of Deleuze and Guattari to conceptualize the rise of empire there is nothing particularly new in Wilson's work, because Hardt and Negri (2000) and to a lesser extent Retort (2005) make use of 
the core thesis of Anti-Oedipus (1972) and A Thousand Plateaus (1984) to understand processes of globalization. But I think that what sets Wilson's treatment apart from these texts is the depth of the textual relation he establishes between the works of the French schizoanalysts and the condition of Americanism.

Similar to the thesis explained by Kroker in The Will to Technology (2003) and Born Again Ideology (2006), The Order of the Joy (2008a) shows how the American war machine expands in order to colonize global space-time on the basis of a ballistic version of Puritanism that we can trace back to the original settlers, but also the core political theorists of America, such as Thomas Hobbes (1982) and John Locke (2003). We know Hobbes employed the new physics of Galileo to conceive of the early modern economy in abstract terms of competing forces, trajectories, and lines of flight that needed minimal regulation in order to ensure that collisions between the human embodiments of those forces continued to be objectified in economic terms and did not break through the thin crust of civilization to restart the natural war of all against all (Spragens 1973). The next step took place when Locke located Hobbes's abstract model of economy in America, the tabula rasa of the new world which was perfectly suited to carrying a metaphysical theory of economy, and began the long history of the mechanization, or technologization, of man through his theory of property that extended to the idea of the estranged possessive individual who owns his own body as an objective source of labor power to be gainfully employed in the world (Macpherson 1962). Given the theoretical model that the English political philosophers left America, which enabled the understanding of men as abstract economic quantums best understood through reference to the new physics of movement that conceived of reality as a smooth space characterized by competing quantums of matter in motion, and money that stands in for some other object and only finds value in relation to other values, it is clear how the possessive individual could be conceived of in terms of a piece of hard metal that was endlessly on the move and was meaningless beyond its relation to the environment that would simply either allow or disallow future movement. Although my view is that the political philosophies of Hobbes and Locke may be seen to inform the development of Americanism on a deep philosophical level, Wilson skips the English masters and leaps straight to Deleuze and Guattari and in particular their idea of the war machine to illuminate the condition of postmodern America. In his view the purpose of the war machine, which represents the fusion of economy, state, and war in American empire, is to brand reality, where the practice of branding simultaneously refers to the ancient process of marking property and the postmodern practice of image manipulation in order to stimulate consumer desire, and code the flows of capital as they pass through space-time in order to continually construct and reconstruct the endlessly deconstructing economic imaginary.

This is where war enters Wilson's system. The practice of war paves the way for flows of fast capital by deconstructing traditional territorial structures in order that new capitalist structures may be constructed in the image of the globalized capitalist body without organs and the state may oversee the construction of the correct essential infrastructure to establish connections between the new virgin territory and the wider imperial network. Hardt and Negri (2000) make the same point in their Empire, suggesting that the key role of the American military machine is to develop smooth space for capitalism to flow through, and Retort (2005) employ the concept of military neo-liberalism to show how the American military machine is led by the principle of economic need in order to first open up and second protect new markets essential for the maintenance of the heated up global consumer credit society. That this heated up consumer model crashed while I was reading Wilson's books illustrates his point that the reason global space-time has become a battleground of competing economic interests is that the traditional master signifier of international relations, the balance of power, which had held since the end of World War II in the form of nuclear deterrence, collapsed with the Berlin Wall and the Soviet Union leaving the globalizing technologies of finance, telecommunications, and the American military machine free to colonize global space-time without human reason or reflexivity.

It is now clear that the essential result of the total unreflexive expansion of these globalizing technologies under the tutelage of the American state over the course of the last twenty years has been the more or less apocalyptic crash of the global economy which was never governed by value rationality, but rather operated on the basis of mindless principles of economic struggle, such as competitive advantage. However, to imagine this crash somehow signals the end of Americanism and that Obama will be presented with a clean slate on which to build a more socialistic America is, I think, a mistake since the standard view of the Chicago School economic thinkers would be to regard the current economic chaos in posthuman terms by suggesting that what has happened over the course of the last year or so is best represented by the image of the personal computer re-booting itself after receiving the essential software update that the credit bubble was over-inflated and needed to burst in order for the economy to start to expand in future. The idea that we should tamper with the economy on the basis of the essential re-boot, and think in humanistic terms about the effects of the re-start on the world's human population, would be lost on a thinker such 
as Milton Friedman (2002), who would assert the need to let the economy work itself out of the downturn, simply because he was possessed by the apocalyptic spirit of technology that has become normal in the Americanized world. Unfortunately for the human population of the planet, the modern / postmodern age has been, and continues to be, defined by the dominance of the spirit of technology in ways that stretch far beyond the economic theories of Friedman and the Chicago School thinkers and are perhaps better illustrated by Heidegger's (1977) theory of completed nihilism that describes a world totally possessed by instrumental reason.

Despite the dire warnings of the prophets of technological dystopia such as Heidegger we remain unable to really conceive of the value of organic life vis-à-vis the vitality of technology because we are infused by the spirit of the machine that has no purpose beyond the endless reproduction of its most basic function to work. As Kroker (2003) illustrates in his The Will to Technology, the prophets of the technological future, such as Marx, Nietzsche, and Heidegger, understood that the machine, which is transformed into Deleuze and Guattari's war machine in Wilson's work, has no thought, philosophy, or reason. It simply works for the sake of working and ensuring that it continues to works in the future. In Kroker's view this image of what Deleuze and Guattari call the mecanosphere was predicted by Marx, who advanced the notion of circulation, Nietzsche, who made the idea of the will central to this thought, and Heidegger, who linked Marx to Nietzsche in his theory of completed technological nihilism that simply wills the will that wills itself and so on. However, we know that this is not the end of the story. Akin to Kroker (2006), who shows that the closed circle of completed nihilism produces a mythical resurrection effect that pushes a primitive God who hires and fires and sort winners from losers centre stage, Wilson explains that the total expansion of the supercapitalist war machine through the various scalings of global space-time produces a utopian moment of convulsive pleasure comparable to the mystical union with an omniscient tech-no God for a post-Nietzschean nihilistic universe.

This is a truly apocalyptic event in Wilson's view because the sensation of anorganic mechanistic joy is the product of the realization of a ghoulish utopia-dystopia of total control or over-determination which sees the supercapitalist machine start to threaten the elimination of organic life itself in favor of a new brand of postorganic cybernetic life that does not suffer from any of the imperfections or malfunctions of its organic predecessor. In this situation the war function and the state function of supercapitalism are merged in the form of a violent control mechanism set on over-determining organic life by transforming it into code that can easily flow through the imaginary body of the globalized communications network in quantums that are equivalent to both basic financial and telecommunications data. Under these conditions, where organic life itself is under threat from the spirit of technology, we have entered the realm of Agamben's (1998) state of exception where there is no rule of law, but that made by those in executive power who manage the endless unfolding of the supercapitalist machine.

For Wilson (2008a), we are currently living in the Americanized supercapitalist state of technological second nature where we are totally exposed to the coding mechanisms of state power. In Agamben's work this means that the liberal individual is completely open to construction through discourse and that they can, therefore, easily be reduced to a state of bare life by stripping away their legal identity. However, Wilson's postmodern, surrealistic, take on the significance of the new coding technologies of the supercapitalist state takes this Foucauldian theory a step further. In his view, the contemporary supercapitalist empire, which is in the process of reducing everything and everybody to the status of code, deconstructs and reconstructs the individual as either normal or pathological on the basis of their sociological and biological identity that flows through the globalized communication network as streamed data. At this point the individual, who has already been reduced to the status of a quantum of economic power by the Hobbesian / Lockean logic of the supercapitalist system, is totally surveilled by the normalizing power structures implicit in the Americanized global communication network.

In many respects this vision of a total system that covers every conceivable scaling on the planet, reaching from the global level of networked communications to the micro-biological level of individual genetic code, represents Foucauldian (2008) biopower in its ultimate form. What the contemporary American supercapitalist war machine achieves through the reduction of the individual to digital data is the complete immersion of humanity into a technological coding system that simply works by endlessly circulating information. The difference between this Americanized biopolitical machine and what Roberto Esposito (2008) calls the archetypal biocracy of modernity, Nazism, is that the Nazi machine was never able to globalize its model of normality and pathology because its central mechanism for reducing humanity to the status of bare life, the camp, remained at an experimental level that required the relatively primitive industrial production of corpses, rather than the system we live with today which creates postindustrial postmodern Muslims or muselmänner through the reduction of humanity to the status of code. In this respect Nazism was nowhere near as effective in achieving the normalization of humanity as the contemporary 
American supercapitalist machine because its mechanism for creating robotic men relied on brutal violence and the systematic humiliation of the embodied human.

We know that the American system sometimes slips back into the same logic, because we have all seen the images from Abu Ghraib, but these kind of events represent a primitive or, in Wilson's Lacanian language, real form of punishment that the supercapitalist war machine would prefer to avoid where possible, simply because it understands that surveillance and normalization through data is a far more effective means of ensuring that humanity is perfectly streamed through the channels of technological mecanosphere than ritual humiliation ever could. However, the supercapitalist machine is not a static system that simply turns over endlessly because the effect of the closure of mechanical circuit is the production of a new mythological subject that functions to make the process of total robotization bearable. What this means is that somewhere in the realization of the total technological system, where the global scale is the micro scale of data that streams across the smooth spaces of the world communication network, we encounter the real end of history in the emergence of a kind of metaphysical temporal loop, which connects the contemporary supercapitalist machine to ancient cosmological notions of the micro-macrocosm that showed how man was intimately related to the universe, and, as a consequence, the violent closure of the circuit of history running from ancient Greece to postmodern America, with the result that humanity is thrown back into prehistory and mythology.

This is what Kroker (2006) means by quantum culture because what it illustrates is the way in which the surrealistic looping of history creates a new space of techno-mysticism based on notions of the kind of apocalyptic rapture popular in contemporary America (Pfohl 2006). But in the new American techno-apocalypse it is not simply that the chosen few vanish into the mystical body of Christ, because this pulp version of the story is far too close to traditional Old Testament thought, but rather that the totally immersed, totally coded, body of the normalized individual is overcome by the fantasy of the bioengineered new man who never wears out and never passes away. In this sci-fi fantasy, which is, in my view, the hard core or real of contemporary supercapitalist ideology, the new man, a kind of bioengineered Nietzschean übermensch, resides in a strange techno-utopia, a new Heaven on Earth characterized by immortality and a culture of endless life, where everybody and everything simply works.

Consider the sci-fi fantasy where everything works. This imaginary, which trades off the construction of cinematic imaginary and star-status in Hollywood, current obsessions with cosmetic surgery and body transfiguration, and the proliferation of hard-core pornography on the primary site of globalization, the Internet, where superhuman, hyper-sexed, bodies provide surrealistic images of hard fucking machines working at maximum intensity in idolization of the supercapitalist machine, not to mention the very real evolving science of bioengineering, sustains the masses' belief in technology. That this fantastic vision seems more real in some places in the world, such as California, than others, which are known for other reasons related to death and destruction, legitimates its ideological function in the minds of the masses who worship those super-human pumped up bodies working and playing at maximum intensity. But the problem with this work hard-play hard ideology of endless life is that it creates a culture of mystical enjoyment based on perfect mechanical motion to screen out what Wilson (2008a) suggests is the truth of the contemporary supercapitalist system, which is death, destruction, and the transformation of humanity into pure malleable data to be bought, sold, and disciplined over the media-scapes of the global communications network.

In this condition, which Wilson expresses through the idea of the death drive of capitalism, humanity is reduced to the status of pure commodity and the veneer of civilization is stripped back to leave the world in what may appear to be a state of nature, but is in reality a condition of manufactured technological brutality. Supported by the ideological fantasy of the post-human body, there is no end to death drive supercapitalism. In the state of manufactured natural brutality one would imagine that the brand of mysticism that Heidegger (1993) employed to suggest a different mode of technology, which would be poetic rather than calculative in its approach to evolution, should be unsustainable. The same should be the case for the fantasy of the utopia of the bioengineered man, simply because in the face of a thanatological system that transforms everybody and everything into an object for exchange, and in a globalized society where the amoralism of evolutionary biology dominates economic thought in the shape of bioeconomics, one would imagine that there would be no room for such a technological fantasy. However, it seems to be that far from undermining the legitimacy of the techno-utopia of the bioengineered superman, the evolution of the contemporary supercapitalist thanatological dystopia that we might call the new Hobbesian ecosystem has in fact led humanity to cling to the fantasy of the technological superhuman more desperately than ever before, perhaps because we collectively realize that there is no way we can stop technology in its tracks and that our only hope of salvation from the impending techno-apocalypse resides in some future utopian technological innovation.

Unfortunately, in Wilson's (2008a) view, the flat line American supercapitalism is likely to produce is not some 
timeless anorganic utopian future where everybody lives out perfect lives, but rather an endless posthistorical present characterized by death, destruction, and the consumption of organic life. This relates to his key criticism of contemporary bioeconomic thought which is that it remains wedded to 19th century notions of sustainable economics and balanced production and consumption and fails to recognize that the supercapitalist machine is not about creating a sustainable economy, but rather consuming and laying waste to everything that crosses its radar in thanatological pursuit of flat line burn out. In this respect Wilson reads contemporary supercapitalism through the lens of Freud's Beyond the Pleasure Principle (2003) that explains how humanity is set on a suicidal path straight back to the state of security first experienced by the unborn in the peaceful nothingness of life in utero and that the only reason we continue to live and do not simply cut our own throats is that we are conflicted creatures who also possess a deep will to live. Fatally caught between the extremes of Dad who tells us to live a little and Mom who wants to keep us close, we live lives characterized by risk and consumption taken in the widest sense of the term in order to establish some kind of compromise formation between living forever and dying as soon as we are born.

Wilson makes the case that Mother Nature has the same problem herself. She realizes she has to let her children live a little or she would have to cancel their existence outright before they had even had chance to let out their primal birth cry. All the same she cannot stand to see them stray too far for fear that they will leave her behind. For Wilson, this is why eating, sex, and death exist in nature. These practices simultaneously prolong life, but also ensure that death will eventually catch up with complex organisms that eat and copulate. In other words, eating and sex have no reason of their own, but exist to ensure that death persists. Thus, Wilson explains that there is no need for creatures to eat each other or starve searching for food because making their own food through photosynthesis would be more effective in terms of sustaining life. Similarly, he tells us that there is no need for creatures to work through the problems of sexual reproduction because simple asexual reproduction or splitting is a more efficient way of ensuring the continuation of life without the combative struggle to reproduce or the essential problem of complex organic life, death. But if this is the case, we are left with the fundamental problematic of waste. Why waste? Following Bataille (1991), Wilson's basic answer to this most basic but profound question is that the universal truth of existence is expenditure. There is no more. We live to waste.

In Wilson's (2008a) view it is this basic truth that animates American supercapitalism. This is why it should be understood as a manufactured technological mode of brutality modeled on the state of nature that is totally ignorant of the value of culture and civilization. His theory of contemporary American supercapitalism shows how the growth of human economy through the stages of industrialism and postindustrialism until the current globalized economic system has resulted in the emergence of an informational ecosystem that treats everybody and everything as economic data to be circulated through the channels of the network in order to enable the production of more value in the form of profit. Although we have seen that this system can generate surplus value ex nihilo in the form of complex economic machines called futures, the hitch is, of course, that somewhere in the process the supercapitalist system needs to consume fresh raw materials. Herein we encounter the martial element of contemporary American supercapitalism, which we may explain through Marx's (1993) theory of primitive accumulation or Retort's (2005) update notion of military neo-liberalism, that Wilson suggests is essential to feed the machine by opening up new territory for exploitation. Given that it is this machine that causes so much poverty, misery, death, and destruction across the world to the extent that today we wonder whether the biosphere will soon become inhospitable for human life, it is difficult not to wonder why we do not simply pull back from the brink now.

Beyond the mystical belief in technology, perhaps the answer to this question is, as Wilson suggests, that we are fated to self-destruct and turn the planet into a black hole that cannot sustain organic life. Despite this thesis, which seems more persuasive every day, I think that we must hope that the power of human reason will save us from ourselves. But even this hope is complicated by the effects of supercapitalism on culture understood in its most basic sense as human meaning symbolized. As Wilson (2008b) shows the problem of culture under conditions of American supercapitalism is that it loses its deep capacity to carry human meaning and instead becomes more data trash in the commodity ecosystem. This is problematic because if we are to even begin to critique the technonihilism of supercapitalism we will have to turn to culture to first create some sense of the significance of organic life in the world and second help us to think through the problems of the thanatological personality of America. But what is even worse is that beyond the Frankfurt School problematic of culture as commodity lay the issue of the ways the commodity form infects cultural content (Adorno and Horkheimer 1997). This results in, for example, the inscription of the suicidal culture of performance in the Nike slogan, Just Do It! What, then, are our prospects of saving ourselves from death-drive America through cultural criticism? This is the subject of the second of Wilson's (2008b) two books on contemporary American supercapitalism, Great Satan's Rage. 


\section{Rage Against The Satanic Supercapitalist Machine}

Great Satan's Rage (2008b) turns off the theoretical model developed in The Order of Joy (2008a) to explore the popular cultural effects of the emergence of the nihilistic supercapitalist machine. In this text Wilson's central thesis is that beyond the production of the mystical techno fantasy of the bioengineered man, which is translated for everyday use by movie-porn-sports stars who enjoy life to the max through perfect bodies, the meaningless supercapitalist system has seen the development of a popular culture of negativity that is peculiarly American in nature. The basic emotion streamed through the culture of negativity is what Heidegger (1993) called the malice of rage, but the sense of nihilism of American supercapitalism similarly expresses itself in cultures of despair, hopelessness, apathy, boredom, sadness, misery, anxiety, and paranoia. Although it is possible to read the production of these cultures of negativity in terms of a process of psychological reaction-formation, which is designed to simultaneously work through and critique the nihilistic technological form of contemporary America, Wilson shows that the relation of the popular culture of negativity to the supercapitalist machine is more complex than first appearances may suggest.

The title of the book itself, Great Satan's Rage, begins to suggest the complexity of the relation between the popular culture of negativity and the wider supercapitalist system for the reader of The Order of Joy, because it works off the idea that it is not simply American popular culture that is possessed by a deep sense of rage, but also the Great Satan, the American state itself, that rages against the world around it. Centrally, it is this bind between the negativity of American supercapitalism and its popular cultural expressions that are simultaneously utterly conservative, because they express the violent negativity and murderous rage that is America, and entirely radical, because this cultural negativity and rage is often directed towards America itself, which holds Great Satan's Rage together and drives the text forward through to its undecided conclusion, in much the same way that violent negativity and murderous rage propel the America supercapitalist system endlessly into the future.

Given the centrality of the idea of conflict to the book, the position of Milton's figure of Satan in the text is particularly important. Milton's Satan is, of course, the rebellious antihero par excellence of Paradise Lost (1993) who struggles with a tyrannical God, only to be cast out of Heaven and forced to live in Hell. Satan's rage emerges from his hatred of his creator and his deluded belief that Dad wants to stop him leading his own life. Although Milton ultimately presents Satan as at best a sulky teen, who simply cannot stand the fact that he is God's creature, and at worst a paranoid conspiracy theorist, who is possessed by psychopathological feelings of hatred for Dad, the equation between the fallen angel and rebellion and revolution has stuck. It is this vision of Satan, the raging rebel without a real cause, that Wilson uses to symbolize America under conditions of supercapitalism. Akin to contemporary America, which was born of rebellion and revolution first when the Puritans fled England and second when the settlers threw their colonial masters out of the new world, Milton's Satan is a born rebel who lives for revolt and revolution but is not, in the end, entirely sure what it is he wants to put in place of the old regime.

Despite his claim that 'it is better to reign in hell than to serve in heaven' (1993:9), it seems that what Satan does know is that he wants to get out of Hell in order to get back in Dad's face. God's two-state solution is clearly no good for Satan because he heads off to the new world as soon as he can in order to cause problems for God's other more recent creation, man. I think it is clear that the reason Satan wants to mess with man, and lead him out of the Garden of Eden where the rules of utopia apply and throw him into the dystopic world of time driven by desire, sin, and the law, is that he wants to provoke Dad who really should have known better than to abandon him to Hell. We know that life in Hell is no life for Satan because his rage against God is marked by deep ambivalence. He hates God because He is creator, everything Satan wants to be, but loves him for the same reason. The problem is that God cannot help his status as creator. He cannot make his creature independent. Satan has to revolt on his own terms. This is exactly what happens in Paradise Lost, but the problem is that rebellion is never enough because Dad is still Dad and Satan's place is not Heaven. This is why the revolution never ends.

In the end Satan's revolution is purely negative, purely nihilistic, since it is based in the rage of the creature who wants to be his own creator. For Wilson the same is true of America. He tells us that Satan's motto 'non serviam' (I will not serve) perfectly describes the American attitude to life, even in the era of supercapitalism when the land of the free is the only super-power on the planet. In Wilson's view, then, the truth of America is that the Puritan revolution never really ended. The sulky states cannot help but see oppression everywhere, because it is still consumed by resentment towards the old world. Similar to Milton's Satan, who really wants to get back to Dad to live out a flat line life in Heaven, but can only express this through hurt fuelled rage, America is driven by a primal desire to reach the oceanic state of the old world that simply exists, which it can only articulate through violent rage 
against examples of oppression that appear to repeat its own colonial past. That all of this is repressed deep into America's cultural unconscious explains why the discourses of freedom, democracy, and individual self-realization, which condition the ideology of progress scratched onto the nihilistic supercapitalist machine and continue to inform the Californian mysticism of the bioengineered man and his organic friend, the movie-porn-sports star, are expressed with complete naivety and total lack of reflexivity, despite the glaring presence of evidence to the contrary, which suggests that America is more often than not engaged in cynical realpolitik. It is this delusional situation, which has evolved through massive military spending set on ensuring that the revolution never ends and the emergence of a politics which is always conditioned by ideas of freedom and more centrally liberation, that has led America to become a world leader that still thinks of itself as an oppressed power.

That America has no sense of itself is, I think, perfectly captured by the reversal of Milton's revolutionary Satan, who Wilson correctly interprets as the romantic antihero of the west, into the Great Satan of the Iranian Revolution that still persists today in the Islamic world. In this view the American Satan is simultaneously John Wayne with horns civilizing the West and an evil imperialist set on the violent exploitation of every available human and environmental resource. Although America seems to be completely unaware of the bipolarity of the figure of Satan, it may be that the schizophrenia of the Devil is perfectly illustrative of the condition of American supercapitalism and its front men, such as George Bush and Donald Rumsfeld, who wanted to present themselves as revolutionaries on the side of freedom, democracy, and human rights, but came off looking like evil colonialists looking to slash and burn what they could not loot.

Wilson knows that the Devil has all the best tunes. As such, he explains that it is possible to find a similar bipolarity in the nihilistic popular culture of supercapitalist America. The bands who soundtrack postmodern America, such as NWA, Ice-T, Nirvana, Korn, and Slipknot, express sincere rage, apathy, and disgust at the world around them, but similarly fail to offer any kind of constructive solution to the dystopic conditions they hate so much. Instead what they offer is images of sensuous violence and complete apathy. In this respect they are totally in tune with the nihilism of American supercapitalism because what they have to offer, rage against the machine, is in no way revolutionary in an extra-systemic sense. Consider one of Wilson's (2008b) key examples, gangsta rap. Gangsta rap evolved in Los Angeles in the early 1980s in response to the rise of Reaganomics and the ruination of the black inner city. Abandoned by policy makers to the ultra-violent state of nature Loic Wacquant (2007) calls the hyper-ghetto, and living in a completely segregated world characterised by the narcotics economy, NWA and Ice-T rapped about the violence of gangsta life. As Wilson explains, their records where characterized by what Chuck D, front man of Public Enemy, called niggativity. For Wilson, Chuck D's point was that the problem with NWA, Ice-T, and later NWA member Ice-Cube, was not only that they produced records that where wholly negative in their representation of the state of hyper-ghetto, because they could surely be forgiven for not producing utopian solutions to the withdrawal of the state from the inner city, but that they also created urban imaginaries that glamorized the ultra-violent world of the dark economy of drugs, gangs, and prostitution.

The term niggativity refers to the way black popular culture plugged into the nihilism of American neo-liberalism and began to glamorize the violence of its central principle, economic competition, through rapped tales of the drug wars that played out supercapitalism in the black community. All of this in order to make a fast buck. But what a fast buck! Now the vicious circle of the nihilist economy was complete: supercapitalism destroys the black community that responds by selling the hyped-up version of that destroyed community to make money in the supercapitalist economy where violence is necessary to produce profit. As the supercapitalist machine heated up over the course of the 1990s, the niggativity of gangsta rap became more extreme. Snoop Doggy Dogg, who had always employed the pimp aesthetic, branched out into hard core pornography, and 50 Cent, produced perhaps the archetypal gangsta hymn to ultra-violent supercapitalism, Get Rich or Die Tryin. In Snoop Dogg and 50 Cent the niggativity of NWA and Ice-T was completed. In completed niggativity there is no longer any trace of criticism of American apartheid, such as that advanced by Chuck D and Public Enemy, because adjustment to the violence of the inner city is complete and the narco-economics of the hyper-ghetto have become an accepted part of American life.

At this point the misery of the hyper-ghetto expressed by sociologists such as Wacquant (2007) is totally overcoded by expressions of the sexualized enjoyment of violence that recalls the key works of Wilson's master thinker Georges Bataille, and the gangsta imaginary is transformed into a fantastical universe of violence, sex, and money, where the normal rules of society no longer apply. It is this cartoon world of fantasy transgression, most clearly illustrated by the New York group Wu-Tang Clan whose 1999 record Enter the Wu-Tang mixed samples from cult martial arts movies, Bushido philosophy, and ultra-violent tales of the hyper-ghetto to create a surrealistic landscape caught somewhere between medieval Japan and postmodern America, which sells to middle-class white 
kids on the basis of the parental advisory sticker, the sign that one is about to enter the fantasy world of the gangsta. Regarding this warning sign, I do not think that the importance of the parental advisory sticker can be underestimated because what this symbol, which was developed by the ultra-conservative Parental Music Resource Centre (PMRC) in the 1980s, really signifies is the kind of Satanic rebellion Milton wrote about in Paradise Lost expressed through violent language that tunes kids into the core values of the nihilistic culture of supercapitalist America, cut throat competition, sadistic enjoyment of violence, complete lack of sympathy for others, hedonistic consumption based on immediate gratification, and total lack of reflexivity, which can never find voice in official discourse because they remain the obscene, unconscious, dystopic truth of Americanism.

Unfortunately, the other popular cultural form Wilson examines, white punk / nu-metal, has not really exposed the problem of Americanism in an overtly political sense either. Instead, the new wave of punk has simply repeated the constructs of gangsta rap for a different sub-cultural audience. Accounting for the emergence of the new form of punk / metal, Wilson suggests that as the niggativity of gangsta became more popular with white kids in the late 1980s, a new fusion of punk-metal emerged on the independent music scene. The new creation, grunge, soon became the music of choice for the hyper-nihilistic, disenfranchised, white kids of generation X. A seemingly endless series of grunge bands exploded from the Seattle Sub-Pop label in the late 1980s / early 1990s, but the key exponents of the form, Nirvana, remained central to the movement even though they 'sold out' to a major record label, Geffen, and produced a number one album, Nevermind, simply because they captured the nihilistic culture of American supercapitalism for white kids so perfectly. Apart from the ironic naming of the band, 'Nirvana', which was simultaneously a sincere recognition of the need for some utopic state of peace and a sarcastic swipe at the impossibility of such a condition, that might be seen to be comparable to Thomas More's (2003) gesture of naming his perfect world Utopia to indicate the impossibility of the place he was describing, the title of the group's most popular record, Nevermind, exemplified the apathy of generation X, who had resigned themselves to lives characterized by misery and boredom before they had even reached adulthood.

In explaining the synthesis of boredom, apathy, and teen angst under the master sign of grunge, rage, Wilson (2008b) provides a contemporary pop cultural example of the condition of the malice of rage that Heidegger (1993) linked to the rise of technology and the emergence of the condition of completed nihilism. Akin to Milton's sulky teen hero, Satan, who was expelled from perfect state of Heaven, the kids of generation X were the cast offs, where the idea of the cast-off refers to the creation of an accursed share or excremental remainder, of a perfectly functioning technological system that has no time for the philosophizing of the young. Since the supercapitalist machine has no time for the eternal question of the young, why? -- and is completely closed to the real experience of wonder before the new -- simply because it is completely cynical in its industrial production of saleable novelty, the original kids of American neo-liberalism were born nihilists or, in the words of Kurt Cobain, negative creeps. That the nihilism of Generation X was in many respects the product of supercapitalism and its reduction of cultural significance to the level of financial calculation is reinforced by the cover art of Nevermind.

As Wilson explains, Nirvana's baby is caught up in the supercapitalist machine and the pursuit of money from the moment it is born. Although the cover star of Nevermind is no new born, his immersion in water recalls the condition of the foetus in the womb, with the implication that the nihilistic logic of the new economy conditions life, not only before the toddler has learnt to speak and entered the symbolic order, but before he has even emerged into the world. Herein resides the reflection of supercapitalist nihilism in Nirvana's outlook on life. If supercapitalism is mother long before it is father, then the thanatological pursuit of peace, nirvana, through a suicidal return to the womb will offer no escape from the torment of a life conditioned by the need to find some kind of meaning in a human world reduced to the meaninglessness of the natural world that simply exists. That Nirvana could never escape this bind is clear. Consider their third and final album that mixed critique of the culture industry, the track Radio Friendly Unit Shifter, with suicidal tendencies, the original title of the record was I Hate Myself and Want to Die, and the metaphor of the womb, the final album title was In Utero. Here, the thanatological strategy of the pursuit of the return to the peace of the womb through self-destruction was played out on vinyl. But even though Cobain took the thanatological route, shooting himself in the head in 1994, he could not save himself from supercapitalism. Suicide is big business, especially in pop music, because it helps to sell records to kids who feel similarly suicidal about their hopeless situation in the supercapitalist machine.

It is likely that death has always been a key theme of popular music, and popular culture more generally, because this form of culture has always been connected to the capitalist culture industry that is endlessly set on reducing human meaning to the calculation of the bottom line. But Wilson (2008b) shows how this condition radicalizes under conditions of supercapitalism, so that it is no longer simply suicide that captures the nihilistic imagination of 
the teen critique of consumer capitalism, but rather the active cultivation of death and destruction through war and combat. In Great Satan's Rage (2008b) this turn from rage conditioned by apathy and suicide to rage characterized by aggression and violence is captured in the shift from the grunge scene of Nirvana to the nu-metal sub-culture of Korn that reflects the shift from Bush I to Bush II and the transformation of war from a cynical political strategy to an existential condition. In this transformation from Bush I through Clinton to Bush II, which represents the movement towards the complete realization of the supercapitalist machine, the rage of bands such as Slipknot and Drowning Pool can be seen as a critical reflection of the violent nihilism of contemporary America that is characterized by anger, aggression, and conformity to the belief in the existential significance of war. That nu-metal is the soundtrack to Bataillean man fighting his way through the war zone of the contemporary supercapitalist ecosystem screaming 'I myself am war' (1985:239) is evidenced by Wilson who notes that American troops in Iraq made Drowning Pool's Bodies their number one theme to the war on terror. In Wilson's view the screamed mantra of Bodies, 'let the bodies hit the floor', perfectly captures the ghoulish supercapitalist utopia-dystopia that has taken root in the neo-colonial spaces of Iraq and Afghanistan.

The lyrics of Bodies juxtapose the line 'nothing wrong with me' to the mantra 'let the bodies hit the floor' in order to suggest that the American war machine is in some way pathological. But contrary to Drowning Pool's equation of the violence of the war on terror with insanity, war and violence are far from pathological in western thought. Consider the key works of Hobbes (1982), Nietzsche (2003b), Marx (1993), Heidegger (1991a; 1991b), Jünger (2004), Marinetti (2008), Bataille (1991), and Deleuze and Guattari (1972; 1984). Milton's Satan, the Puritan Devil of resistance, rebellion, and revolution, is in each of these thinkers. He possesses them, manifesting himself in the commitment to negativity and overcoming, which has been more or less completely realized in supercapitalist America. This is why Wilson's use of the Nietzschean tradition of French thought is perfectly appropriate to the study of contemporary America and there is nothing arbitrary about his use of Bataille and Deleuze and Guattari to understand the system he calls supercapitalism. As Kroker (2006) explains in his study of technology, it is not only that the Nietzschean tradition sheds light on contemporary globalization, but rather that contemporary globalization is in many respect the realization of the current of nihilism and negativity running through western thought. To call the violent hot spots of the contemporary world, such as New Orleans, Mexico City, Juarez, Caracas, Gaza City, Baghdad, and Mogadishu, Bataillean spaces is, therefore, in no way simply descriptive, because these urban war zones are realizations of the prophetic insights of the French thinker and his fellow Nietzscheans who saw supercapitalism coming long before Bush II was pushed center stage.

Given that the Nietzscheans' central lesson of supercapitalism is that struggle is an existential condition, the difference between war and peace in the supercapitalist world is relatively unimportant. Whether we choose to focus on Detroit, Mexico City, or Kabul the war is always on. War is everywhere in the supercapitalist world. In sports, which represent the most popular escape route from the hyper-ghetto, conflict, suffering, and pain are considered necessary to success. Even in education, the space of culture, civilization, and learning, there is no escape from warfare. As Wilson (2008b) explains, Columbine and the Virginia Tech shootings illustrate that the core principles of supercapitalism (compete, consume, produce) form the hidden curriculum of contemporary education. War is, in Wilson's language, the hidden excess-essence or x-essence of the contemporary Americanized world. From the drug wars that rage across the hyper-ghettos of Los Angeles, Mexico City, Juarez, and Sao Paulo, to the violent response to criminality of the supercapitalist warfare state, there is no end to spiral of violence because in Wilson's view struggle is what the Americanized world is all about. This is the negative utopia of America, the negative utopia of first freedom, where we are free to fight for our right to survive, second democracy, because we know everybody is part of the fight to survive, and third individualism, because we understand that we are on our own, that everybody else is either predator or prey, and that the role of the state is to ensure that the basic Hobbesian rules of engagement hold and no more.

Possessed by the malice of rage that comes from living in a technological world that is completely devoid of human tolerance, the spirit of Milton's Satan possesses every Americanized one of us. Possessed individuals, the rebel nation orders us to resist. You will not serve, unless you are working the counter of McDonalds or Wal-Mart, in which case you must fall in line with the hyper-rational machine of supercapitalism that embodies the principle of resistance. Refusal to obey the negative program to not serve will paradoxically be interpreted in offensive terms and result in massive resistance on the part of the Satanic machine. War, the normal modus operandi of the supercapitalist machine, will be the end result. This is why war in no way opposes the supercapitalist machine and the radical Islamists are misguided if they think that their actions will have any impact upon American neo-colonial policy. As Wilson (2008a) suggests, the exploding body of the suicide bomber is a secret joy to the supercapitalist 
war machine because what it signifies is the passing of humanity and the emergence of the completed nihilism of the posthuman machine that simply works.

Contrary to war, which simply plays into the hands of the war machine, what we require to oppose supercapitalism is cultural resistance and cultural change. This is what makes Wilson's books, which may strike some readers as totally over the top, so important. They offer resistance to the contemporary American-led capitalist war machine on the basis of their hyperbolic critique of state violence that escapes the hegemonic symbolic order of the culture industry through its surrealistic refusal of the mass man who wants to be told what he already knows to be true. Unfortunately, what mass man knows to be true is the symbolic structure that we must recognise, resist, and overcome if we are to ever work through the problem of not only contemporary post-modern capitalism, but also more fundamentally the dystopic strain of Americanism understood in its widest sense. Thus, Wilson's books are true edge works in that they that seek to engage the reader who refuses engagement in order to question his total adjustment to the normal madness of contemporary capitalism. In this respect they are impossible texts in that they are critical cultural studies working in the fundamentalist Americanized world where there is no place for critique or culture that does not conform to the norm set out by the culture industry that sells to the normal man on the street. It is here, in their very impossibility, that Wilson's books retain the kind of weak messianic power, which he finds in contemporary popular culture, and is essential for the kind of cultural critique we find in true American utopians such as C Wright Mills, that we must urgently re-discover in the era of completed supercapitalist nihilism or what I call death drive America.

\section{References}

Adorno, T. and M. Horkheimer. 1997. Dialectic of Enlightenment. London: Verso.

Agamben, G. 1998. Homo Sacer: Sovereign Power and Bare Life. Palo Alto, CA: Stanford University Press.

Arendt, H. 1973. The Origins of Totalitarianism. New York: Harvest Books.

Bataille, G. 1985. 'The Practice of Joy Before Death.' Pp. 235-240 in Visions of Excess: Selected Writings, 1927-1939. Minneapolis: University of Minnesota Press.

-----. 1991. The Accursed Share: Volume I. New York: Zone Books.

Deleuze, G. 1991. Masochism: Coldness and Cruelty and Venus in Furs. New York: Zone Books.

Deleuze, G. and F. Guattari. 1972. Anti-Oedipus: Capitalism and Schizophrenia: Volume I. London: Athlone.

-----. 1984. A Thousand Plateaus: Capitalism and Schizophrenia: Volume II. Minneapolis: University of Minnesota Press.

Esposito, R. 2008. Bios: Biopolitics and Philosophy. Minneapolis: University of Minnesota Press.

Featherstone, M. 2007. Tocqueville's Virus: Utopia and Dystopia in Western Social and Political Thought. London: Routledge.

Foucault, M. 2008. The Birth of Biopolitics: Lectures at the College De France, 1978-1979. Basingstoke: Palgrave.

Freud, S. 2003. Beyond the Pleasure Principle. London: Penguin.
Friedman, M. 2002. Capitalism and Freedom. Chicago: University of Chicago Press.

Hardt, M. and A. Negri. 2000. Empire. Cambridge, Mass: Harvard University Press.

Heidegger, M. 1977‘The Question Concerning Technology.' Pp. 3-36 in The Question Concerning Technology and Other Essays. New York: Harper and Row.

----. 1991a. Nietzsche: Volumes I and II. San Francisco: Harper.

-----. 1991b. Nietzsche: Volumes III and IV. San Francisco: Harper.

-.-.-. 1993. 'Letter on Humanism.' Pp. 213-267 in Basic Writings. San Francisco. Harper.

Hobbes, T. 1982. Leviathan. London: Penguin.

Jünger, E. 2004. Storm of Steel. London: Penguin.

Kroker, A. 2003. The Will to Technology and the Culture of Nihilism: Heidegger, Nihilism, Marx. Toronto: University of Toronto Press.

----. 2006. Born Again Ideology: Religion, Technology, and Terrorism. Victoria: Ctheory Books.

Locke, J. 2003. Two Treatises of Government and a Letter Concerning Toleration. New Haven, CT: Yale University Press.

Macpherson, C. B. 1962. The Political Theory of Possessive Individualism: Hobbes to Locke. Oxford: Oxford University Press. 
Marinetti, F. 2008. 'War, Sole Cleanser of the World.' Pp. 53-55 in his Critical Writings. New York: Farrar, Straus, and Giroux.

Marx, K. 1993. Capital: Critique of Political Economy: Volume I. London: Penguin.

Mbembe, A. 2003. 'Necropolitics.' Public Culture 15(1):11-40.

Milton, J. 1993. Paradise Lost. London: Penguin.

More, T. 2003. Utopia. London: Penguin.

Morone, J. 2003. Hellfire Nation: The Politics of Sin in American History. New Haven, CT: Yale University Press.

Nietzsche, F. 2003a. Thus Spoke Zarathustra. London: Penguin.

-----. 2003b. The Birth of Tragedy. London: Penguin.

Pfohl, S. 2006. Left Behind: Religion, Technology, and the Flight from the Flesh. Victoria: Ctheory Books.
Retort. 2005. Afflicted Powers: Capital and Spectacle in the New Age of War. London: Verso.

Spragens, T. 1973. The Politics of Motion: The World of Thomas Hobbes. Lexington, KY: University Press of Kentucky.

Virilio, P. 2001. 'From Modernism to Hypermodernism and Beyond: An Interview with Paul Virilio.' Pp. 25-57 in Paul Virilio: From Modernism to Hypermodernism and Beyond, edited by J. Armitage. London: Sage.

Wacquant, L. 2007. Urban Outcasts: A Comparative Sociology of Advanced Marginality. Cambridge: Polity.

Wilson, S. 2008a. The Order of Joy. Albany: SUNY Press.

-----. 2008b. Great Satan's Rage: American Negativity and Rap/ Metal in the Age of Supercapitalism. Manchester: Manchester University Press. 
